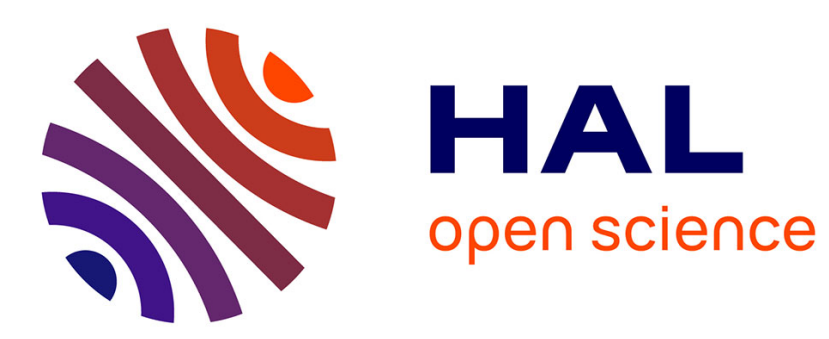

\title{
There is an alternative: Challenging the logic of neoliberal penality \\ Emma Bell
}

\section{To cite this version:}

Emma Bell. There is an alternative: Challenging the logic of neoliberal penality. Theoretical Criminology, 2014, 18 (4), pp.489 - 505. 10.1177/1362480614534880 . hal-01662063

\section{HAL Id: hal-01662063 \\ https://hal.univ-smb.fr/hal-01662063}

Submitted on 15 Dec 2017

HAL is a multi-disciplinary open access archive for the deposit and dissemination of scientific research documents, whether they are published or not. The documents may come from teaching and research institutions in France or abroad, or from public or private research centers.
L'archive ouverte pluridisciplinaire HAL, est destinée au dépôt et à la diffusion de documents scientifiques de niveau recherche, publiés ou non, émanant des établissements d'enseignement et de recherche français ou étrangers, des laboratoires publics ou privés. 


\title{
There is an alternative: Challenging the logic of neoliberal penality
}

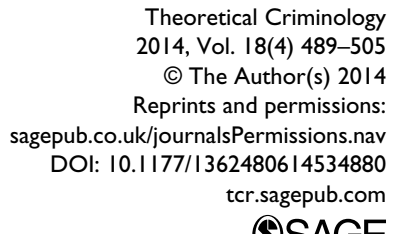

Theoretical Criminology 4. Vol. 18(4) 489-505

(C) The Author(s) 2014

k/journalsPermissions nav @SAGE

\section{Emma Bell}

Université de Savoie, France

\begin{abstract}
This article seeks to sketch out alternatives to neoliberal penality by seeking to undermine the four institutional logics of neoliberalism as identified by Loïc Wacquant (2009). It begins by critically analysing the potential value of public criminology as an exit strategy, suggesting that whilst this approach has much value, popular versions of it are in fact rather limited on account of their exclusion of offenders themselves from the debate and their optimism about the capacity of existing institutions to challenge the current punitive consensus. It suggests that a genuinely 'public' criminology should be informed by an abolitionist stance to both current penal policies and the neoliberal system as a whole. This may be the best means of truly democratizing penal politics.
\end{abstract}

\section{Keywords}

Abolitionism, democratization, neoliberal penality, public criminology, punitiveness

\section{Introduction: There is no alternative?}

Announcing her plan to tackle inflation via strict monetarist policies at a press conference in 1980, Thatcher famously declared 'we have to do it. Because there really is no alternative' (Thatcher, 1980). TINA, ${ }^{1}$ a commonly used acronym for the idea that There Is No Alternative to neoliberal policies, has been accepted by all subsequent governments in the UK and by a considerable number of governments elsewhere around the world. Tony Blair accepted his neoliberal Thatcherite inheritance as a given and David Cameron has justified the coalition's programme of spending cuts,

\footnotetext{
Corresponding author:

Emma Bell, Department of Literature, Languages and Human Sciences (LLSH), Campus de JacobBellecombette, Université de Savoie, Rue Jean-Baptiste Richard, BP I I04, Chambéry Cedex, 730 I I, France. Email: emma.bell@univ-savoie.fr
} 
declaring, 'If there was another way I would take it. But there is no alternative' (Cameron, 2013). If there really is no alternative to neoliberalism, current punitive trends are likely to continue since it is the context of neoliberalism that has made recourse to tough penal policies such an attractive option for government ministers of all political hues seeking re-election (Bell, 2011). Many specialists question the emphasis placed on neoliberalism in explaining punitive trends, highlighting differences in institutional and political cultures' (Lacey, 2008; Zedner, 2002) and the existence of counter-trends to punitiveness in Europe and within the United States (McBride, 2013: 229-232; Nelken, 2009; Tonry, 2009). It is certainly true that there are differences in levels of punitiveness even within national territories. Furthermore, neoliberalism is applied in extremely diverse ways across the globe as it adapts to local political and institutional cultures. I do not intend to suggest that forging an alternative political consensus to neoliberalism would mean that penal policies would automatically become more progressive-punitive policies can thrive and have thrived under a great variety of political regimes. Yet, there are a sufficient number of similar trends at play in the penal policies adopted by countries caught in the grip of neoliberalism to make a causal link. As I have argued elsewhere (Bell, 2011), it is indeed neoliberalism that makes resort to such policies so politically attractive at present, even if other factors may also be at play. Hall (2011: 9) has argued that 'naming neoliberalism is politically necessary, to give resistance content, focus and a cutting edge'. Similarly, I believe that it is politically important to discuss neoliberal penality if we seek to resist it and the punitive trends it engenders. The aim of the present article is to focus on the case of the UK, exploring ways in which the logic of neoliberal penality may be undermined, paving the way for alternatives.

This is no mean feat. Even a number of political commentators who deplore the nefarious effects of neoliberal policies remain pessimistic about alternatives (Crouch, 2011; Gamble, 2009). By extension, it may be assumed that there really is no alternative to neoliberal penality: to ever-increasing prison populations, increased criminalization and the blurring of the boundaries between penal and welfarist measures. Some of the most vociferous critics of neoliberal penality may even be held responsible for encouraging such stasis, myself included, on account of the fact that they have often failed to sketch 'the outlines of alternative futures' (Loader and Sparks, 2013: 112). It should be noted that there are some notable exceptions such as Thomas Mathiesen (1974a) and, most recently, David Scott (2013a, 2013b) who has set out a project for an 'abolitionist real utopia' in two separate publications. Nonetheless, the apparent lack of concrete exit strategies from the current punitive impasse in penal politics has in recent years led some criminologists, most notably Ian Loader and Richard Sparks in the UK, to sketch out some exit strategies of their own under the banner of 'public criminology' (Loader and Sparks, 2010a, 2010b, 2012, 2013).

The aim of this article is to suggest here that it is possible to move beyond neoliberalism and to move beyond the punitive penal policies. It will first critically explore 'public criminology', as it is defined by Loader and Sparks, as a possible exit strategy before moving on to propose a more genuinely 'public' form of criminology, inspired by the tradition of penal abolitionism, as an alternative exit strategy. 


\section{Public criminology as exit strategy}

Over the past decade and more, there has been much discussion of 'public criminology'. The notion is often understood in terms of making criminology more 'relevant' to public policy just as Michael Buroway (2005) famously argued that sociology needs to engage more directly with the public and policy-makers in his presidential address to the American Sociological Association in 2005. A flurry of debate in the fields of both sociology and criminology followed Burawoy's call (notably in the journals Criminology and Public Policy and Theoretical Criminology) yet, as many of those engaged in the debate recognized, the notion of a public criminology is far from new. As Uggen and Inderbitzin (2010: 735-737) point out, there has been 'a great history of public criminology', with influential criminologists such as Lloyd Ohlin actively involved in advising John F Kennedy in the Great Society project in the 1960s (2010: 735) and conservative criminologists such as James Q Wilson involved in advising the Reagan administration. As Wacquant (2011: 439) points out, the tradition of linking specialized knowledge to public action is even longer than Uggen and Inderbitzin suggest: 'the debate public criminology broaches is a variation on the time-honoured question of the relationship between social knowledge and public action with a view towards justice, a question posed long ago by the Marquis of Condorcet, Auguste Comte and Emile Durkheim'.

Why then the renewed interest in public criminology today? It seems this needs to be understood in the particular context in which crime policy is developed today, namely one in which the issue is increasingly 'heated up', sensationalized and politically - rather than evidentially — driven (Loader and Sparks, 2010a). This may be understood as a climate of anti-democratic authoritarian populism (Hall, 1988) whereby genuine public fears are manipulated by policy-makers for electoral advantage. As Hall et al. (1978) made clear in their 1978 oeuvre, such a strategy is most likely to be adopted when the state is suffering from a severe crisis of legitimacy. In 1978, this crisis was one of authority prompted by the disintegration of the post-war consensus. Constructing the 'law and order society' became a means for the state to unite the citizenry against a common 'enemy within', in this case the black mugger, capable of embodying all of the fears and anxieties of the époque. From the 1990s onwards, the state entered into a new phase of crisis as the socially deleterious effects of neoliberalism became evident. The evident social and now economic failure of neoliberalism has prompted a severe crisis of legitimacy on a scale akin to that which followed the collapse of the post-war consensus in the 1970s. Once again, there has been a renewed focus on law and order: as the state has lost interest in providing social security, it is ever-more imperative for the state to at least appear to offer greater physical security and to find suitable scapegoats for social problems (Bell, 2011, 2013a, 2013b; Garland, 2001). It is in this specific context that the crime problem has been 'heated up'. This is not to suggest that there are not other factors at play, notably the move away from a more deferential form of decision making (Loader, 2006; Ryan, 2005) and towards a society increasingly dominated by a 24/7 news media obsessed with headline-grabbing stories which are more likely to demonize than analyse and seek to understand offenders. Nonetheless, the renewed crisis of state legitimacy prompted by the adoption of neoliberal politics which work against the interests of vast swathes of the population is of central importance. 
For Loader and Sparks, the response to the current heated-up policy-making climate should not be to turn away from the public but rather to endeavour to foster genuine, rational debate between academics, policy-makers and the public. It is about moving from populism to democracy - the criminological endeavour is to be regarded as a task of 'democratic underlabouring' whereby the criminologist engages with rather than turns away from politics, becoming involved in democratic debate to contribute to 'a better politics of crime and its regulation' (Loader and Sparks, 2010a: 117). It is in this way that public criminology may perhaps be regarded as a possible exit strategy from the 'hot' climate of neoliberal penality, even though Loader and Sparks do not present the argument in precisely these terms (indeed, they appear to dispute the impact of neoliberalism on punitive trends).

In order to examine the idea of public criminology as exit strategy further, it is necessary to understand precisely what is meant by a 'better politics of crime'. For Loader and Sparks (2013), it is about creating genuine democratic legitimacy rather than Gramscian hegemony. They do not regard such legitimacy as something which already exists but rather as a realistic ideal to aspire to by invoking a language that is already understood by policing and penal institutions. It is in this sense that they argue that it is an 'unfinished' ideal, borrowing Thomas Mathiesen's (1974a) idea that it is necessary to move beyond what already exists, sketching out alternatives rather than providing elaborate blueprints for change. They consequently remain rather vague about what penal alternatives which promote democratic legitimacy might actually consist of but, drawing on the work of the philosopher Pierre Rosanvallon, they suggest that democratic legitimacy might develop around his three key notions of legitimacy: the legitimacy of impartiality; the legitimacy of reflexivity; and the legitimacy of proximity. The legitimacy of impartiality entails developing institutions which can 'watch the few on behalf of the many' (Loader and Sparks, 2013: 116). Such 'impartial' institutions already exist in the form of 'ombudsmen, inspectorates of police, probation and constabulary, independent police complaints commissions, prison monitoring boards, information and surveillance commissioners, lay visitors, commissions of inquiry and so on' but they need to be more open to democratic input (2013: 116). The legitimacy of reflexivity entails developing human rights discourse and judicial oversight in such a way that democratic institutions are constantly forced to reflect upon and question their actions outside of the normal electoral cycle (2013: 117-118). Loader and Sparks give as an example of such politics in action the mobilization of civil society to expose the truth about the police handling of the Hillsborough Stadium Disaster in which 96 football supporters died (Hillsborough Independent Panel, 2012). Finally, the legitimacy of proximity is seen to lie in the building of a genuine democratic consensus by bringing officials, experts and citizens together and ensuring that procedural fairness is respected when this does occur (Loader and Sparks, 2013: 118-119).

While Loader and Sparks regard the future of such democratic legitimacy as 'unfinished', they do nonetheless appear to see some cause for optimism in what already exists. For example, in an earlier article, entitled 'Beyond lamentation', ${ }^{2}$ they note the increased role played by human rights (Loader and Sparks, 2012: 19) which they believe can 'offer basic protections for the individual against state's coercive intrusions and place necessary constraints on the scope and reach of penal power' (2012: 29). Consequently, they 
underline the need to develop a 'human rights ethos' in policing and penal institutions whether these be public or private (2012: 29). They also highlight the changes which have taken place within criminal justice institutions, noting that the police now 'operate under forms of routine, sceptical scrutiny (and are to this extent more alert to the conditional nature of their legitimate authority) that were quite unknown during the midtwentieth century heyday of policing "by consent"” (2012: 19).

\section{The limits of public criminology as it is commonly defined}

Much of what is put forward by Loader and Sparks as public criminology is of significant value in terms of pointing the way towards alternatives to the current punitive penal consensus that characterizes neoliberal penality today: prioritizing human rights; changing the focus from state legitimacy to democratic legitimacy; moving beyond a crimeoriented politics towards one that focuses on encouraging social justice. However, there are a number of problems with Loader and Sparks' approach which mean that it may have difficulty realizing these ideals and thus producing genuine alternatives to present policies.

First, their approach tends to focus on improving existing institutions. They suggest that it is possible to 'revitalise and (re)invent police and penal institutions in order that they become active agents of just ordering' (Loader and Sparks, 2012: 27) to be understood as 'a renewed social democratic politics of order' (2012: 30). As noted above, they believe it is possible for these institutions to develop a truly human rights ethos. It is true that human rights legislation has at times placed limits on police powers, notably on the wide use of stop and search powers (see Gillan and Quinton v. United Kingdom [2009] ECHR 28), and that some of the most punitive aspects of criminal law have been watered down because they failed to respect basic human rights, notably the indefinite detention of terrorist suspects under the Anti-Terrorism Crime and Security Act 2001. Nonetheless, a human rights ethos has manifestly not developed within existing criminal justice institutions. Despite the significant reforms made to the English police service following the murder of Stephen Lawrence in 1993 and the subsequent Macpherson Inquiry (Macpherson, 1999), the police are still believed to be 'institutionally racist' (Rollock, 2009) and their practices have changed little since the Human Rights Act 1998 (see Bullock and Johnson, 2012). Similarly, it has been asserted that no human rights culture has been instilled in the prison service (Eady, 2007). Given the pressures on the public sector to compete for government contracts to run prison and probation services and the increasing involvement of the private sector (Bell, 2013a, 2013b), it is likely that those involved in running such services will be more preoccupied by cost considerations than those of human rights and offender welfare. The situation is not helped by the current government's open opposition to human rights legislation and its failure to comply with the European Court of Human Rights over controversial issues such as the blanket ban on prisoner voting. Furthermore, the coalition government's decision to cut public funding drastically for legal aid under the Legal Aid, Sentencing and Punishment of Offenders Act 2012 will mean that it will become particularly difficult for individual citizens to uphold their human rights. 
Loader and Sparks' optimism concerning the development of a human rights culture in existing institutions would therefore appear to be misplaced. Indeed, existing institutions have a very long way to go before they can become institutions of 'just ordering'. It is unlikely that they will be forced to change by a more active citizenry as Loader and Sparks hope. Indeed, even when citizens have come together with experts to challenge criminal justice institutions, such as during the Hillsborough Inquiry cited above, little change has resulted. The Independent Police Complaints Commission is currently carrying out an investigation into police behaviour following the Hillsborough disaster but many have criticized the slow progress of the report. In any case, it is unlikely that it will satisfy victims' demands to hold the police to account given that the organization lacks teeth: the body has difficulty accessing sensitive police records and is liable to 'regulatory capture' meaning that those charged with regulation are likely to be too close to the police and largely dependent on police support (Savage, 2013).

This focus on improving existing institutions is reminiscent of the 'left realist' arguments of the 1980s according to which the police, the courts and the rule of law can be invoked in the defence of the working class who suffer most from crime (Lea and Young, 1984). There is an extreme risk that this form of public criminology, like left realism, ${ }^{3}$ will allow itself to be co-opted by the very institutions which it strives to render accountable. Also like left realism, Loader and Sparks' public criminology seems to be content to limit its project to guaranteeing formal equality while ignoring the fact that existing institutions are manifestly incapable of delivering substantive equality vis-a-vis the criminal law.

All this would suggest that it will in practice be difficult to foster democratic legitimacy in the sense intended by Loader and Sparks. The legitimacy of impartiality will be hard to foster so long as the organisms which are intended to watch over state institutions lack real power. This in turn affects the legitimacy of reflexivity as these institutions may develop a sense of impunity whereby they merely have to pay lip service to human rights and basic democratic principles. The legitimacy of proximity will then be undermined as an ever-wider gap opens up between the citizens and the institutions which are meant to represent them. Focusing on improving existing institutions renders the 'unfinished' character of the legitimacy project proposed by Loader and Sparks somewhat questionable as their 'alternatives' risk being 'defined in' to existing institutional discourses.

Loader and Sparks (2013: 120-121) do seek to avoid being 'defined in' by moving beyond the 'how' of legitimacy which focuses on institutions to look also at what they call the 'who' or 'what' of legitimacy. While they do not sketch out what exactly they mean by the 'who' or the 'what', reading what precedes we can assume that they mean that the 'what' refers to what institutions should comply with legitimacy requirements, namely public, private and voluntary institutions. This is a valid point: as is suggested below, there is much difficulty involved in making private institutions adhere to the same standards as public institutions. The 'who' most probably refers to the public who need to be involved in building a renewed democratic penal politics. Indeed, Loader and Sparks (2012: 31) highlight the need for institutions to adopt 'priorities and practices [that] are meaningfully shaped by, and minimally credible to, all those who are affected by them'. This seems to respond to Burawoy's (2005: 7-9) call that it is necessary to engage different publics both within and outside the academy in dialogue. However, the 
notion of democratic engagement adopted by Loader and Sparks is rather narrowly defined. Nowhere do Loader and Sparks highlight the need to include all those affected by crime and the criminal justice process in debates about alternatives. While they refer to citizens and the public, they do not refer to offenders themselves. It seems rather odd that they are inspired by Mathiesen's notion of the 'unfinished' but ignore his call to engage offenders themselves in crime politics.

If we are to be serious about addressing the 'who' and 'what' of legitimacy, we need to be looking at offenders themselves, at who the criminal justice process currently targets and at who it excludes. Such an analysis would instantly draw attention to the illegitimacy of a system which treats the powerful and the powerless in entirely different ways. The aim is not just to exercise punitive penality in reverse, refocusing the system on the crimes of the powerful. Highlighting the fact that harmful behaviour is widespread across society, regardless of social class, may be one way of humanizing offenders who fill the ranks of the marginalized and thus making it easier to calm punitive sentiment. We also need to look at what the criminal justice system actually does, focusing on the harm it causes and its spectacular failure to address the multifarious forms of harm experienced in contemporary capitalist societies, thus undermining its legitimacy. Finally, we need to understand why the system functions in the way it does in order to be able to address the conditions which are currently driving such ineffective and illegitimate penal policies. This ought to be the true function of criminologists and all those who are interested in the crime question.

\section{Reorienting public criminology}

Perhaps the fundamental flaw with many of the alternative routes for penal policy proposed is that they underestimate the role of neoliberalism in creating the conditions in which punitive policies are most likely to thrive. Yet, forging genuine alternative penal policies entails first tackling the problem at source. While neoliberalism is certainly not the only 'source' of punitive penal policies, it is one significant factor which makes recourse to such policies more likely. Challenging the logic of neoliberal penality entails confronting each one of the four institutional logics of neoliberalism itself or at least addressing the aspects of those logics which impact most significantly on penal policy. These four institutional logics, as set out by Loï Wacquant (2009: 307), are as follows: '1) economic deregulation ...;2) welfare state devolution, retraction, and recomposition ...;3) the cultural trope of individual responsibility ...; [and] 4) an expansive, intrusive, and proactive penal apparatus.'

With regard to the first institutional logic of neoliberalism, economic deregulation, its most direct impact on the penal sphere has been the privatization not just of criminal justice institutions but also of criminological knowledge. The privatization of criminal justice establishments and services has contributed to penal punitiveness. It may encourage the use of incarceration given that expansion of the prison estate via the involvement of the private sector can be presented as a cost-effective measure (even if this is far from being the case-see later and Prison Officers' Association, 2011). Furthermore, conditions in private prisons may be particularly poor (Bell, 2011: 185-187). A recent report into the newly opened (April 2012) 1600 bed HMP Oakwood prison managed by G4S 
revealed high levels of assaults and victimization, limited time out-of-cell and engagement in purposeful activity and poor healthcare provision (HM Inspectorate of Prisons, 2013). Under the rules of commercial confidentiality, it is particularly hard to hold private institutions to account (Prison Reform Trust, 2005: 7).

The privatization drive cannot alone explain the rise in prison populations but it is one element of current trends which may be a contributing factor to penal expansionism. It is essential to expose the fallacy of arguments used by the government to justify recourse to the private sector, notably those which present the latter as being more costeffective. As Ian Loader (2010: 355) notes, the public may be particularly receptive to arguments highlighting the excessive costs of punitiveness in times of economic crisis. At the end of 2012 , Ministry of Justice spending totalled $£ 8.55$ bn, including $£ 3.58$ bn for the National Offender Management Service (prisons and probation) (Guardian Datablog, 2012). Law, order and defence expenditure as a percentage of GDP in Britain is higher than in any other EU country and even higher than in the USA (OECD, 2012). It is unlikely that the use of the private sector will significantly reduce government expenditure in these areas (see Bell, 2011: 184-185). Indeed, a review of the research with relation to the cost-effectiveness of private prisons in the United States shows that any cost-savings made are very small and short-term only and 'come at the expense of institutional and public safety' (Rizzo and Hayes, 2012: 9). Although cost per prisoner may be lower in private prisons, there are many hidden costs to the state with regard to private prisons. For example, as with all Private Finance Initiative contracts, ${ }^{4}$ there are very high costs of management consultancy and the state will have to continue to pay private sector companies for their services for many years after penal institutions and services have effectively been privatized (Bell, 2011: 185). In any case, it is unlikely that cost considerations alone will be sufficient to bring about a radical change in policy without a fundamental rethink concerning the logic of penal punitiveness itself (McBride, 2013). Furthermore, even if a desire to cut costs was to lead to less quantitative punitiveness in terms of a reduction in prison populations, this may lead to more qualitative punitiveness. For example, those responsible for the running of prisons, whether they belong to the public or private sector, may be led to make cost reductions that will significantly increase the pains of imprisonment (Bell, 2011: 186). This is why it is important not to focus on cost considerations alone when tackling penal punitiveness. Humanitarian and moral considerations must also be taken into account, as suggested below.

Yet there is at least an opportunity to challenge the current government's privatization and marketization agenda which, as outlined above and more fully elsewhere (Bell, 2011), may be regarded as a key driver of punitive trends. The private sector has recently become embroiled in a number of high-profile scandals. In the UK, it was revealed in 2013 that G4S and Serco, the private security companies which earn approximately $£ 1.5$ bn of public money each year via contracts with government departments (Butt, 2013), have been overcharging the government by millions of pounds for offender monitoring services. At the time of writing (November 2013), the companies are being investigated by the Serious Fraud Office. In 2012, G4S who was awarded the security contract for London's Olympic Games, famously failed to provide enough security personnel, forcing the government to bring in police and armed forces to fill the gap at a cost of millions 
of pounds to the UK taxpayer. Such scandals help to undermine public confidence and the neoliberal mantra of private sector efficiency.

It will nonetheless not be sufficient to challenge the privatization agenda in order to bring about genuine penal alternatives. Indeed, the entire neoliberal logic of costeffectiveness and efficiency that informs current penal policies needs to be undermined. This may be done by highlighting the ineffectiveness of current penal measures in terms of preventing crime and rehabilitating offenders. But a more effective approach would be one that adopts a human rights perspective that responds to offenders as people with problems rather than as risks to be managed. There is of course a great deal of popular and official criticism of human rights discourse in the UK, largely fuelled by counterdiscourses of otherization. This is why it is so important to include offenders themselves in the debate, a point I will return to below.

The commodification of criminological knowledge, encouraged by neoliberalism, is another significant impediment to developing alternatives and a truly public criminology. It is thus rather surprising that Loader and Sparks (2010a; Wacquant, 2011: 441444) do not discuss this trend in their book on public criminology. Increasingly, knowledge is regarded as yet one more marketable item which may be sold off to public and private institutions. This has been encouraged in the UK by the immense pressures which now exist to attract research external funding - these pressures were already great some years ago (Hillyard et al., 2004; Hope, 2004; Maguire, 2004; Walters, 2003, 2005,2007 ) but are even more significant under the current coalition government which cut the higher education budget by 7 per cent in just one year (2011-2012) (Guardian Datablog, 2012). When forced to make their research agenda attractive to outside interests, there is a grave risk that researchers will be co-opted and their work carried out in the best interests of sectional interests rather than for the public at large. This is particularly true of research of a critical nature. Indeed, Pat Carlen (2012: 23) writes that critique is often 'inimical to powerful interests'. Research which seeks to be 'public' in the sense of influencing policy-making processes is often 'rebuffed, filleted, appropriated, or reinterpreted in an intensely political environment' (Rock, 2010: 764). This state of affairs highlights the need to make criminological knowledge available to a much wider public if it is to have a genuine impact upon debate. This entails bringing it not just to policy-makers but to all those affected by the criminal justice system, another point that I will return to below.

The second institutional logic of neoliberalism which needs to be challenged is the retraction of the welfare state. The 'rolling back' of the welfare state has not led to spending cuts: it has instead entailed the undermining of the universalist principles upon which the welfare state was founded as the system has become increasingly conditional on behaviour with only the most 'deserving' model citizens being regarded as eligible for support. This would suggest that the real purpose of welfare state retraction has been ideological and political. It is about instilling a competitive and individualistic culture across society by pursuing a deliberate strategy of inequality (Jones and Novak, 1999) and attempting to remoralize society. For Thatcher, this entailed breaking from the 'dependency culture'; for Blair it was all about 'playing by the rules' and instilling respect; for Cameron it is about challenging the values of the 'broken society'. The means to bring about these changes were themselves extremely coercive, for example, 
threatening the unemployed with loss of benefits if they do not turn themselves into model jobseekers. Such policies were not particularly effective at controlling the poor and I would suggest, contrary to Wacquant, that this was not their primary aim. Instead they aimed to be deliberately divisive, serving to unite the 'respectable majority' behind the neoliberal project and divert attention from the real causes of unemployment and social insecurity (Bell, 2011).

In order to challenge the logic of welfare retraction, it is necessary to focus attention on the link between the neoliberal policies adopted by governments over the past 30 years and more and social problems. This will help to avoid the scapegoating of the poor and disadvantaged for these problems. To demolish the myth of welfare scroungers it would also be useful to revive Richard Titmuss' (1958) famous notion of the social division of welfare via which he demonstrated that in practice the welfare state serves the middle classes more than the poor and the working classes, contrary to what many people believe. Most importantly, redefining the parameters of the debate would be a good way of focusing attention on insecurities other than those generated by crime. Again, the present context should facilitate this given that many of those who previously felt secure are starting to feel the pinch of the coalition's austerity policies - perhaps we are seeing a return to 'middle-class pauperdom' (Gray, 1996: 11). Only then will it be possible to depoliticize crime, an essential step towards building alternative criminal justice policies (Scott, 2013a: 316).

The third institutional logic of neoliberalism which needs to be challenged is 'the cultural trope of individual responsibility'. It is the idea that individuals are all ultimately responsible for their own actions that justifies tough penalties for those who fail to be self-sufficient in the labour market and those who fail to respect the law. This culture of 'egotistic individualism' (Reiner, 2007: 18) helps to fuel punitive attitudes, facilitating the government's manipulation of public opinion in the creation of 'suitable enemies' (Christie, 1986). Yet, it does appear that punitive attitudes may be malleable. With regard to crime, they tend to soften when given more information about particular cases and offender backgrounds (Hough and Roberts, 2003). With regard to welfare, public attitude surveys suggest the British public to be rather punitive (Clery et al., 2013) but again, if given more details about the recipients of welfare, perhaps these attitudes might soften. In order to pave the way for alternatives, it is essential to bring about a cultural change which embraces solidarity as opposed to naked individualism.

Yet, it may seem unrealistic to attempt to foster solidarity while social inequalities are so great (Wilkinson and Pickett, 2010) and there is such widespread vilification of the poor (Jones, 2011) and offenders both by the popular media and by government. It is therefore essential to 'humanise aliens and monsters' (Scott, 2013a: 317-318). This is why it is so important not to exclude offenders themselves from the debate about crime and punishment. Criminologists should not just disseminate knowledge about crime but also about those who are convicted of crime. But, most importantly, offenders themselves must be allowed to speak out and participate in the debate. Lack of such participation was highlighted by Thomas Mathiesen back in 1965 as a key obstacle to penal reform (Mathiesen, 1965). Today, prisoner participation is encouraged via the Inside-Out programme whereby university students enter the prison and sit down with incarcerated men and women to discuss issues of crime and justice and make policy recommendations 
(see Werts, 2013). This is a relatively recent initiative but efforts to include those most affected by the criminal justice system go back to the 1960s with the creation of radical penal lobby groups bringing together prisoners, activists, academics and policy-makers (see Mathiesen, 1974b). These were followed in Britain in the 1970s with the establishment of RAP, Radical Alternatives to Prison (see Ryan, 1978; Sim, 2006; Van Swaaningen, 1997: 138-141). RAP sought to bring together all those involved by the criminal justice system (with the notable exception of crime victims who incidentally I believe it is important to include) and to campaign for change. It had some notable successes, namely helping to push for the closure of the isolationist psychiatric control units opened within prisons to contain those labelled as trouble-makers. It is genuine public participation such as this, involving the grassroots, which may lead to a way out of the current punitive impasse (Barker, 2013). Indeed, this may be the best way to confront Wacquant's (2009: 307 ) fourth institutional logic of neoliberalism, notably 'an expansive, intrusive, and proactive penal apparatus $[\ldots$ which $]$ unfurl[s] disciplinary supervision over the precarious fractions of the postindustrial proletariat, and to reassert the authority of Leviathan so as to bolster the evaporating legitimacy of elected officials'. Tackling Leviathan will entail challenging not just state power but also the power of the private sector with whom the British government has come to form a mutually beneficial coalition, much stronger than that which exists between the Conservatives and the Liberal Democrats (Bell, 2014). Power must be returned to the people. This is no easy task given the erosion of Marshallian citizenship (Marshall, 1950) whereby individuals who fail to respect their duties to civil society are increasingly excluded from the normal rights of citizenship. Yet, it is imperative to try to engage those who feel excluded from the body politic in order to rally society together around new alternatives. Solidarity is essential since, as Marquand (2004: 141) has put it, 'The best defence against the arrogance of power is power.'

True democratic power is most likely to emerge out of the adoption of an abolitionist stance, "the attitude of saying "no" as Mathiesen (2008: 58) has put it. As a profoundly critical approach to current problems, it is a way of truly empowering the people, of giving actors and social movements the necessary knowledge to challenge the current penal and political common sense. As a stance that questions the power of mainstream criminal justice professionals and the centralized state (Cohen, 1988: 25), it does not sit well with a public criminology which seeks to work with those same institutions. Indeed, given that it is those institutions which define crime, they help to create it in a sense. They cannot be regarded as the solution. Nonetheless, some abolitionists recognize that it may be possible to work with formal criminal justice institutions such as the police and the courts but only so that it may become possible to influence these institutions in an abolitionist way (see, for example, Hulsman, 1997: 12). This entails linking these institutions to the grassroots. Thus it may be possible to ensure that the authorities do not 'have a monopoly on how to define what goes on in the relevant life world' (Mathiesen, 2008: 61). For Ruggiero (2012: 157), abolitionism has always been the most public of criminologies in that it focuses on the grassroots, on collective actors and social movements rather than on policy-makers, legislators and the media. Reorienting public criminology thus involves moving beyond public criminology as it is currently most widely defined in Britain today, notably by Loader and Sparks. It entails reviving a truly public and 
democratic form of criminology which was originally found in the writings of the penal abolitionists in the 1970 s. It is not enough to be policy-relevant - criminology must provide genuine alternatives to the penal status quo, policies guided by a 'fantastic sense of the possible' (Cohen, 1988: 28). This is 'practical utopianism': it is practical because it provides concrete policy alternatives, but utopian in the sense that it 'rejects any criminology that bases its world-view on the definitional activities of the very system that is its subject of study' (Cohen, 1988: 28).

Practical alternatives to the current punitive consensus must be developed in coordination with all those affected by the system, including victims and offenders themselves. Yet, perhaps the first and most obvious step towards building alternatives needs to come from above. National governments could immediately reduce the prison population by passing a moratorium on prison construction, by decriminalizing certain behaviours, by applying prison amnesties, by sentencing reforms providing for shorter sentences and so on (see Scott, 2013a: 320). Yet, in order for this to be politically possible, they will need to build a popular consensus around such a project. This cannot be done simply by highlighting practical considerations, such as those of cost, but also by flagging up the moral failure of the prison, showing how it serves only to exacerbate the social problems that lead to problematic behaviour in the first place. It will only be possible for the public to understand such issues once they become intimately acquainted with the prison and those who are confined within its walls. Only then can all parties work together to build viable radical alternatives to formal criminal justice processes. Community justice may be a way forward, provided these are not backed up by the threat of incarceration, becoming a mere extension of the formal system, as has occurred with some restorative justice programmes, notably in Northern Ireland (Convery et al., 2008). Safeguards protecting individual rights would also need to be put in place.

\section{Challenging TINA}

Working towards the abolition of the prison (except in the most exceptional of cases) needs to be joined up with efforts to abolish the neoliberal system itself. Indeed, as Reiner (2012: 147) points out, following Stan Cohen, there is a need to address the 'fundamental causes' of punitive policies and thus he argues for the need to 'bring political economy and ethical critique back in'. We must seek to delegitimize neoliberalism and challenge TINA mentalities, replacing 'common sense' with 'good sense' (Hall and O'Shea, 2013).

The financial crisis of 2008 was a perfect opportunity for change but rather than being successfully exploited by opponents of neoliberalism, it has instead been used by the neoliberals themselves as an opportunity to reinforce their project. It is essential to redefine the terms of the debate and to present the crisis as one of neoliberalism. As Gamble (2009: 141) has highlighted, 'It matters which explanation of the crisis becomes dominant, because that will shape the political response. Interpretations of the crisis become part of the politics of the crisis.' This has certainly been the case so far with current economic problems across Europe being blamed on previous governments' mishandling of the economy rather than on the neoliberal system itself. For the free marketeers, the problem is not neoliberalism but the fact that neoliberalism has not been applied to the 
letter, blaming the recent financial crisis on what Hayek described as 'malinvestments', investments financed on credit alone. Commonly, the problem is presented as one of overspending, thus legitimating the adoption of austerity measures.

Furthermore, national governments constantly assert that they have little room for manoeuvre in a globalized economy in which companies are free to move capital around the globe in search of the most favourable fiscal and labour market regime. They argue that they are further constrained by international regulations imposed by organizations such as the International Monetary Fund, forced to comply with what Gamble (2009: 98) has described as 'disciplinary neoliberalism'. Yet, such arguments exaggerate the extent to which companies are genuinely free to move (ignoring 'sunk costs', for example) and tend to present the rules of the global economy as forces of nature which cannot be controlled. This ignores the fact that these rules were largely established by the very same nations which claim they cannot escape their discipline. The same nations could just as well remodel these rules if the political will existed to do so. At present, it does not since all major parties, in the UK at least, adhere to the current neoliberal consensus which underpins the discipline of the global marketplace. This does not, however, mean that nation states have sacrificed the power to alter the current rules of the global market. Rather than sacrifice sovereignty, nation states have simply pooled sovereignty together to enforce their will. The political elites of individual nation states have not just adapted to the rules of the global marketplace but played an active role in developing these. In the same way that they have used their power to free up the market, enforcing financial and labour market deregulation, for example, they could in theory use this power to forge new rules or to at the very least tame the worst excesses of neoliberal global capitalism.

Delegitimizing neoliberalism and seeking to undermine its key logics will allow a greater focus to be placed on achieving social justice. It is to be hoped that this would become the principal means of legitimizing the state as was the case when the key institutions of Britain's welfare state were being laid post-1945. This is not to advocate a return to the past, to a much more deferential society when the public were largely excluded from decision-making processes. It is to advocate genuine democratization: the creation of a new kind of politics, driven neither by corporate nor political elites, capable of moving away from populism and becoming truly popular. Perhaps this would entail the people appropriating the 'big society' for themselves rather than allowing it to be used as a rhetorical device for advancing the interests of big government and the big market (Bell, 2014). Similarly, the notion of 'public' criminology needs to be re-claimed from the academics. A genuinely public criminology should not just aim to engage with policy-makers but also with all those affected by the penal system, be they offenders, victims or onlookers. It also needs to recognize the importance of challenging the logic of neoliberalism which, despite its rhetoric, is profoundly anti-democratic, massively increasing the power of the state. Only then will it be possible to develop a genuinely public and democratic debate on crime and social issues and to move beyond neoliberal penality.

\section{Notes}

I would like to thank David Scott and the three anonymous reviewers for Theoretical Criminology for the helpful comments they provided after reading through this article. I would also like to thank 
José Ángel Brandariz and his team at the University of A Coruña for giving me the opportunity to debate possible exit strategies from neoliberal penality with Richard Sparks and others at a conference entitled 'Beyond Neoliberalism? Politics and Punishment in Contemporary Societies' organised in early October 2013.

1. The term was first used by the leader of the House of Commons, Norman St John Stevas (1979-1981), to refer to Margaret Thatcher and her dogmatism.

2. This essay was largely written in response to Reiner's (2006) essay entitled, 'Beyond risk: A lament for social-democratic criminology' in an attempt to 'cheer him up' (Loader and Sparks, 2012: 22) by pointing to some causes for optimism.

3. New Labour claimed to be inspired by left realism, presenting the crime problem as a working class issue. Yet, it distorted the original meaning of the concept by failing to heed its exponents' call to tackle the 'capitalist' causes of crime - that is, structural inequalities. Instead, New Labour's focus on the causes of crime was almost entirely aimed at changing individual behaviour (see Bell, 2011).

4. The Private Finance Initiative (PFI) was originally introduced under the John Major government of 1992 before being rapidly expanded under successive New Labour governments. It encourages private funding of public services under partnerships forged between the public and private sectors.

\section{References}

Barker V (2013) Prison and the public sphere: Toward a democratic theory of penal order. In: Scott D (ed.) Why Prison? Cambridge: Cambridge University Press, 125-146.

Bell E (2011) Criminal Justice and Neoliberalism. Basingstoke: Palgrave Macmillan.

Bell E (2013a) The prison paradox in neoliberal Britain. In: Scott D (ed.) Why Prison? Cambridge: Cambridge University Press, 44-64.

Bell E (2013b) Punishment as politics: The penal system in England and Wales. In: Ruggiero $\mathrm{V}$ and Ryan M (eds) Punishment in Europe: A Critical Anatomy. Basingstoke: Palgrave Macmillan, 58-85.

Bell E (2014) Reconfiguring the state under the Coalition: Shoring up state power through the Big Society. Observatoire de la société britannique 15. Available at: http://osb.revues.org/.

Bullock K and Johnson P (2012) The impact of the Human Rights Act 1998 on policing in England and Wales. British Journal of Criminology 52: 630-650.

Burawoy M (2005) For public sociology. American Sociological Review 70(1): 4-28.

Butt E (2013) When companies charge the taxpayer for monitoring the dead. openDemocracy, 12 July. Available at: http://www.opendemocracy.net/ourkingdom/ellie-butt/when-companiescharge-taxpayer-for-monitoring-dead (accessed 10 November 2013).

Cameron D (2013) Speech on the economy, 7 March. Available at: http://www.conservatives. com/News/Speeches/2013/03/Prime_Ministers_Speech_on_The_Economy.aspx (accessed 10 November 2013).

Carlen P (2012) Criminological knowledge: Doing critique; doing politics. In: Hall S and Winlow S (eds) New Directions in Criminological Theory. Oxon: Routledge, 15-37.

Christie N (1986) Suitable enemies. In: Bianchi H and Van Swaaningen R (eds) Abolitionism: Towards a Non-Repressive Approach to Crime. Amsterdam: Free University Press.

Clery L, Lee L and Kunz S (2013) Public attitudes to poverty and welfare 1983-2011. Available at: http://www.natcen.ac.uk/media/137637/poverty-and-welfare.pdf (accessed 10 November 2013).

Cohen S (1988) Against Criminology. New Brunswick: Transaction Books. 
Convery U, Haydon D, Moore L and Scraton P (2008) Children, rights and justice in Northern Ireland: Community and custody. Youth Justice 8(3): 245-263.

Crouch C (2011) The Strange Non-Death of Neoliberalism. Cambridge: Policy Press.

Eady D (2007) Prisoners' rights since the Woolf Report: Progress or procrastination? The Howard Journal 46(3): 264-275.

Gamble A (2009) The Spectre at the Feast: Capitalist Crisis and the Politics of Recession. Basingstoke: Palgrave Macmillan.

Garland D (2001) The Culture of Control: Crime and Social Order in Contemporary Society. Oxford: Oxford University Press.

Gray J (1996) After Social Democracy: Politics, Capitalism and the Common Life. London: Demos.

Guardian Datablog (2012) Government spending by department, 2011-12. Available at: http://www.guardian.co.uk/news/datablog/2012/dec/04/government-spending-department-2011-12 (accessed 10 November 2013).

Hall S (1988) The Hard Road to Renewal. London: Verso.

Hall S (2011) The neoliberal revolution. Soundings 48: 9-28.

Hall S and O'Shea A (2013) Common-sense neoliberalism. In: Hall S, Massey D and Rustin M (eds) After Neoliberalism. Available at: http:/www.lwbooks.co.uk/journals/soundings/ manifesto.html (accessed 10 November 2013).

Hall S, Critcher C, Jefferson T, Clark J and Roberts B (1978) Policing the Crisis. London: Macmillan.

Hillsborough Independent Panel (2012) Hillsborough: The Report. London: The Stationery Office. Hillyard P, Sim J, Tombs S and Whyte D (2004) Leaving a 'stain upon the silence': Contemporary criminology and the politics of dissent. British Journal of Criminology 44(3): 369-390.

HM Inspectorate of Prisons (2013) Report on an unannounced inspection of HMP Oakwood. Available at: http://www.justice.gov.uk/downloads/publications/inspectorate-reports/ hmipris/prison-and-yoi-inspections/oakwood/oakwood-2013.pdf (accessed 14 March 2013).

Hope T (2004) Pretend it works: Evidence and governance in the evaluation of the Reducing Burglary Initiative. Criminal Justice Matters 4(3): 287-308.

Hough M and Roberts JV (2003) Youth Crime and Youth Justice: Public Opinion in England and Wales. London: Institute for Criminal Policy Research/The Nuffield Foundation.

Hulsman L (1997) Themes and concepts in an abolitionist approach to criminal justice. Available at: http://www.loukhulsman.org/Publication/ (accessed 14 March 2013).

Jones C and Novak T (1999) Poverty, Welfare and the Disciplinary State. Oxon: Routledge.

Jones O (2011) Chavs: The Demonisation of the Working Class. London: Verso.

Lacey N (2008) The Prisoners' Dilemma: Political Economy and Punishment in Contemporary Democracies. Cambridge: Cambridge University Press.

Lea J and Young J (1984) What Is to be Done about Law and Order: Crisis in the Eighties. Harmondsworth: Penguin.

Loader I (2006) Fall of the 'Platonic guardians': Liberalism, criminology and political responses to crime in England and Wales. British Journal of Criminology 46(4): 561-586.

Loader I (2010) For penal moderation: Notes towards a public philosophy of punishment. Theoretical Criminology 14(3): 349-367.

Loader I and Sparks R (2010a) Public Criminology. Oxon: Routledge.

Loader I and Sparks R (2010b) What is to be done with public criminology? Criminology and Public Policy 9(4): 771-781.

Loader I and Sparks R (2012) Beyond lamentation: Towards a democratic egalitarian politics of crime and justice. In: Newburn T and Peay J (eds) Policing: Politics, Culture and Control. Oxford: Hart, 11-41. 
Loader I and Sparks R (2013) Unfinished business: Legitimacy, crime control and democratic politics. In: Liebling A and Tankebe J (eds) Legitimacy and Criminal Justice. Oxford: Oxford University Press.

McBride K (2013) Why prison? Incarceration and the Great Recession. In: Scott D (ed.) Why Prison? Cambridge: Cambridge University Press, 213-232.

Macpherson W (1999) The Stephen Lawrence Inquiry. London: Home Office.

Maguire M (2004) The Crime Reduction Programme in England and Wales: Reflections on the vision and the reality. Criminal Justice Matters 4(3): 213-237.

Marquand D (2004) Decline of the Public. Cambridge: Polity.

Marshall TH (1950) Citizenship and Social Class. Cambridge: Cambridge University Press.

Mathiesen T (1965) Problems and Possibilities for the Future: Resistance to Change in Correctional Institutions: Synopsis of a Report. Strasbourg: Council of Europe.

Mathiesen T (1974a) The Politics of Abolition. New York: John Wiley \& Sons.

Mathiesen T (1974b) The prison movement in Scandinavia. Crime and Social Justice 1: 45-50.

Mathiesen T (2008) The abolitionist stance. Journal of Prisoners on Prisons 17(2): 58-63.

Nelken D (2009) Comparative criminal justice: Beyond ethnocentrism and relativism. European Journal of Criminology 6: 291-311.

OECD (2012) OECD factbook 2011-2012: Economic, environmental and social statistics. Available at: http://www.oecd-ilibrary.org/economics/data/oecd-factbook-statistics factbook-data-en (accessed 10 November 2013).

Prison Officers' Association (2011) Briefing paper: The Private Finance Initiative and the hidden costs of prison privatisation. Available at: http://www.poauk.org.uk/index.php?prisons-arenot-for-profit-1 (accessed 14 March 2014).

Prison Reform Trust (2005) Private Punishment: Who Profits? London: PRT.

Reiner R (2006) Beyond risk: A lament for social-democratic criminology. In: Newburn T and Rock P (eds) The Politics of Crime Control: Essays in Honour of David Downes. Oxford: Oxford University Press, 7-49.

Reiner R (2007) Law and Order: An Honest Citizen's Guide to Crime and Control. Cambridge: Polity Press.

Reiner R (2012) What's left? The prospects for social democratic criminology. Crime Media Culture 8(2): 135-150.

Rizzo E and Hayes M (2012) An assessment of the risks and benefits of prison privatization. Available at: http://www.anselm.edu/Documents/Academics/Departments/Criminal\%20 Justice/DOC\%20Privatization\%20Final\%20Report.pdf (accessed 10 November 2013).

Rock P (2010) Comment on 'public criminologies'. Criminology and Public Policy 9(4): 751-767. Rollock N (2009) The Stephen Lawrence Inquiry Ten Years On: A Critical Review of the Literature. London: The Runnymede Trust.

Ruggiero V (2012) How public is public criminology? Crime Media Culture 8(2): 151-160.

Ryan M (1978) The Acceptable Pressure Group. Inequality in the Penal Lobby: A Case Study of the Howard League and RAP. Farnborough: Saxon House.

Ryan M (2005) Engaging with punitive attitudes towards crime and punishment: Some strategic lessons for England and Wales. In: Pratt J, Brown D, Brown M and et al. (eds) The New Punitiveness: Trends, Theories, Perspectives. Cullompton: Willan Publishing, 139-149.

Savage S (2013) Thinking independence: Calling the police to account through the independent investigation of police complaints. British Journal of Criminology 53: 94-112.

Scott D (2013a) Unequalled in pain. In: Scott D (ed.) Why Prison? Cambridge: Cambridge University Press, 301-324.

Scott D (2013b) Visualising an abolitionist real utopia. In: Malloch M and Munro B (eds) Crime, Critique and Utopia. Basingstoke: Palgrave Macmillan, 90-113. 
Sim J (2006) The abolitionist approach: A British perspective. In: Jewkes Y and Johnston H (eds) Prison Readings: A Critical Introduction to Prisons and Punishment. Cullompton: Willan, 98-104.

Thatcher M (1980) Press conference for American correspondents in London, 10 Downing Street, 25 June. Available at: http://www.margaretthatcher.org/document/104389 (accessed 11 November 2013).

Titmuss R (1958) Essays on the Welfare State. London: George Allen and Unwin.

Tonry M (2009) Explanations of American punishment policies: A national history. Punishment Society 11: 377-394.

Uggen C and Inderbitzin M (2010) Public criminologies. Criminology and Public Policy 9(4): 725-749.

Van Swaaningen R (1997) Critical Criminology: Visions from Europe. London: SAGE.

Wacquant L (2009) Punishing the Poor: The Neoliberal Government of Social Insecurity. Durham, NC: Duke University Press.

Wacquant L (2011) From 'public criminology' to the reflexive sociology of criminological production and consumption: A review of Public Criminology by Ian Loader and Richard Sparks. British Journal of Criminology 51: 438-448.

Walters R (2003) New modes of governance and the commodification of criminological knowledge. Social Legal Studies 12(1): 5-26.

Walters R (2005) Boycott, resistance and the role of the deviant voice. Criminal Justice Matters 62(1): 6-7.

Walters R (2007) Critical criminology and the intensification of the authoritarian state. In: Barton A, Corteen K, Scott D et al. (eds) Expanding the Criminological Imagination: Critical Readings in Criminology. Cullompton: Willan, 15-37.

Werts T (2013) Reflections on the Inside-Out prison exchange program. The Prison Journal 93(2): $135-138$.

Wilkinson R and Pickett K (2010) The Spirit Level: Why Equality Is Better for Everyone. London: Penguin.

Zedner L (2002) Dangers of dystopia. Oxford Journal of Legal Studies 22(2): 341-366.

\section{Author biography}

Emma Bell is senior lecturer in British Studies at the University of Savoie in Chambéry. She is the author of Criminal Justice and Neoliberalism (2011) and the current coordinator of the European Group for the Study of Deviance and Social Control. 